\title{
Evaluation of the Safety and Efficacy of a Live Attenuated Thermostable Rift Valley Fever Vaccine in Sheep, Goats and Cattle
}

\author{
Daouam $\mathbf{S}^{3^{*}}$, Ghzal $\mathrm{F}^{2}$, Arkam AE${ }^{1}$, Naouli $\mathrm{Y}^{2}$, Jazouli $\mathbf{M}^{2}$, Ennaji $\mathbf{M M}^{3}$, Tadlaoui KO${ }^{1}$, Oura $\mathrm{C}^{4}$ and Elharrak $\mathbf{M}^{1}$ \\ ${ }^{1}$ Research and Development Virology, Multi-Chemical Industry, Morocco \\ ${ }^{2}$ Laboratory of Quality Control, Multi-Chemical Industry, Morocco \\ ${ }^{3}$ Laboratory of Virology, Hygiene \& Microbiology, Faculty of Sciences \& Technics, University Hassan II Mohammedia-Casablanca, 20650 Mohammedia, Morocco \\ ${ }^{4}$ School of Veterinary Medicine, University of the West Indies, Trinidad and Tobago
}

"Corresponding author: Daouam et al., Multi-Chemical Industry, Sud-Ouest (ERAC) B.P: 278 Mohammedia, Morocco, Tel: +212659748333; E-mail: s.daouam@mcisanteanimale.com

Received date: Aug 26, 2015; Accepted date: Oct 21, 2015; Published date: Oct 26, 2015

Copyright: (C) 2015 Daouam S, This is an open-access article distributed under the terms of the Creative Commons Attribution License, which permits unrestricted use, distribution, and reproduction in any medium, provided the original author and source are credited.

\begin{abstract}
Rift valley fever (RVF) is a highly significant vector-borne disease causing huge economic loses in livestock (ruminants and camels) and also human fatalities. The disease is endemic in most Sub-Saharan African countries, including West Africa, and has been present in the Middle East since 2010. Vaccination is considered to be the most effective way to prevent and control the expansion of the disease.

Currently available attenuated live vaccines for RVF have significant limitations in that they are either thermolabile (CL13 strain vaccine) or causes abortion and teratogenic effects (Smithburn strain vaccine). This study therefore set out to develop a safe and effective thermostable live attenuated RVF vaccine. The existing CL13 vaccine, which is a naturally attenuated strain, was made thermostable through three cycles of heating $\left(56^{\circ} \mathrm{C}\right)$ and selection. The resulting candidate vaccine $(\mathrm{CL} 13 \mathrm{~T})$ was stable at $4^{\circ} \mathrm{C}$ for 20 months and shows significantly improved levels of thermostability over the existing CL13 vaccine.
\end{abstract}

A pilot batch of the CL13T vaccine was produced and tested for safety and efficacy in cattle, sheep and goats. The vaccine was found to be safe, with no clinical signs or side effects observed in vaccinated animals, and there was no evidence for circulation of the virus in the blood of animals post-vaccination. On testing for efficacy in cattle, sheep and goats, through the detection of neutralizing antibodies post-vaccination, good levels of neutralizing antibodies were detected for a minimum of one year in sheep and goats, and neutralizing antibodies were detected for least 4 months in cattle.

This new thermostable vaccine could represent an efficient tool for the control of rift valley fever in endemic countries. The vaccine also has the potential to be used, along with an appropriate diagnostic test, to differentiate vaccinated from infected animals (DIVA).

Keywords: Rift valley fever; Thermostable; Clone 13T vaccine; Sheep; Goat; Cattle

\section{Background}

Rift valley fever virus (RVFV) belongs to the Phlebovirus genus of the Bunyaviridae family. It is a segmented, single-stranded RNA virus composed of three segments: the large $(\mathrm{L})$, the medium $(\mathrm{M})$, and the small (S) [1]. RVFV causes a viral zoonotic vector-borne disease known as rift valley fever (RVF). The disease is characterized by high levels of mortality of young animals and abortions in pregnant females. Affected species include sheep, goat, cattle and camel. Humans can also be infected by mosquito bites, and importantly by exposure to the blood and tissues from infected ruminants during slaughter, necropsy or while assisting aborting animals [2]. Naturally infected animals develop high viremia sufficient to infect arthropod vectors, even if the infection is clinically in apparent [3]. In contrast to human disease, RVF manifests as "abortion storms" in several adult livestock species and in infected newborns, mortality approaches 100\% [4-6].
Initially confined to sub-Saharan Africa and Egypt [6], the virus emerged out of the African continent in 2000 to cause a major enzootic/epidemic in the Arabian Peninsula [7]. In 2006/07, in Kenya, Somalia and Tanzania, the disease caused more than 1000 human infections with 323 deaths. The virus then spread to Madagascar, Comoros and Mayotte islands in 2008 [8,9]. Recent studies have shown the presence of RVF infected camels in North Africa in 2011 [10], as well as outbreaks in Mauritania and Senegal [11].

Vaccines currently being used in RVF endemic countries such as South Africa and Kenya include the live-attenuated Smithburn strain vaccine and a formalin inactivated aluminum hydroxide adjuvanted vaccine, based on a low passage wild RVF strain [12]. Though effective, both of these vaccines have limitations preventing their potential use. The live attenuated vaccine (Smithburn strain) induces early and longterm immunity after a single injection [13] however it is not recommended for use in early-stage pregnant ewes [5,14]. The inactivated whole virus vaccine requires at least two initial administrations followed by annual revaccination $[15,16]$. 
The RVFV clone 13 (CL13) strain is a naturally attenuated strain of RVFV. It is a mutant strain carrying a large deletion in the nonstructural protein coded by the S segment (NSs), which was isolated from a non-fatal human case of RVF in the Central African Republic [17]. Vaccination using the CL13 strain has been demonstrated to be safe and efficacious in sheep, goats and calves using a single vaccination $[18,19]$. However, a recent study revealed that this vaccine is unstable at temperatures above $22^{\circ} \mathrm{C}$, raising the risk associated with using this vaccine in the tropical (hot) countries without strict maintenance of the cold chain during vaccine storage and delivery [20]

The objectives of this study were firstly to develop a thermostable CL13 vaccine, through the isolation of a derivative thermostable clone from the original CL13 strain, and secondly to evaluate the safety and efficacy of the new thermostable vaccine through the measurement of vaccine related RVFV, RVFV RNA and neutralizing antibodies in the blood post-vaccination in target species (sheep, goats and cattle).

\section{Materials and Methods}

\section{Isolation and characterization of the thermostable RVFV CL13T candidate vaccine}

The RVFV CL13 strain was propagated on Monkey African Green kidney (Vero) cells, heated to $56^{\circ} \mathrm{C}$ and resistant viral particles were selected by the limited dilution method. Serial dilutions of the virus were prepared and titrated in 96 well plates. Virus from the highest dilution showing cytopathic effect was considered a resistant clone and was selected for the next passage. Three cycles of heating and selection were carried out and the most stable clone, which was named Clone 13T (CL13T), was passaged on Vero cells and its kinetics of multiplication, infectious titre and thermostability was compared with the original CL13 strain. The RVFV was handled under BSL-3 laboratory conditions in biosafety class III gloved boxes.

To determine their replication kinetics, each of the selected clones were inoculated at a multiplicity of infection (MOI) of 0.01 on 4 Vero cell flasks grown and maintained in DMEM with $10 \%$ irradiated fetal calf serum. The inoculated flasks were incubated at $37^{\circ} \mathrm{C}$ in a $5 \% \mathrm{CO}_{2}$ atmosphere. Every 24 hours one of the four flasks was frozen at $-80^{\circ} \mathrm{C}$ and titrated. Titres were calculated by the Reed-Muench method and expressed by $\mathrm{TCID}_{50} / \mathrm{ml}$.

\section{Thermostability of the RVFV CL13T candidate vaccine}

Viral suspensions of both vaccine strains (CL13T and CL13) were tested for stability by periodic titration after heating in water bath at $37^{\circ} \mathrm{C}, 45^{\circ} \mathrm{C}$ and $56^{\circ} \mathrm{C}$ as follows:

- At $37^{\circ} \mathrm{C}$, with aliquots of virus titrated daily for 4 days.

- At $45^{\circ} \mathrm{C}$, with aliquots of virus titrated every $30 \mathrm{~min}$ for $180 \mathrm{~min}$.

- At $56^{\circ} \mathrm{C}$, with aliquots of virus titrated every $10 \mathrm{~min}$ for $90 \mathrm{~min}$.

Both strains were mixed V/V with a stabilizer (4\% peptone, $8 \%$ sucrose and $2 \%$ glutamate), lyophilized and tested for stability after storage 20 months at $4^{\circ} \mathrm{C}$ and 7 days at $37^{\circ} \mathrm{C}$.

\section{Safety and efficacy testing of the CL13T candidate vaccine in animals}

All animal experiments were carried out in accordance with guidelines for the care and handling of experimental animals. The animal experiments were approved by the ethics committee in charge of the control and supervision of experiments on animals and the experiments were conducted in high containment level 3 facilities. Prior to the experiment, all the animals were confirmed to be negative for antibodies to RVFV by ELISA and virus-neutralization (VN) as described in the OIE Manual [21]. After vaccination, rectal temperatures was recorded daily, and the animals were monitored daily for clinical signs including weakness, respiratory signs and general wellbeing. Antibody responses were analyzed weekly for 8 weeks, then monthly.

Six to nine month-old calves were randomly divided in 5 groups of 6 calves. Each group of 6 calves was vaccinated by the subcutaneous (SC) route using different doses of the CL13T vaccine, from $10^{4}$ to $10^{8}$ $\mathrm{TCID}_{50}$. Vaccinated animals were observed and sampled for a period of 4 months. A group of 6 sheep and a group of 6 goats, all 3-6 months old, were vaccinated with $1 \mathrm{ml}$ of $10^{3} \mathrm{TCID}_{50}$ of the RVFVCL13T vaccine by the SC route. A further group of 2 sheep and 2 goats were used as unvaccinated controls. The 4 unvaccinated controls were housed in the same pen as the vaccinated animals.

Blood collected in EDTA tubes was tested for the presence of the vaccine virus genome by real-time RT-PCR [22] from day 0 to day 15 post vaccination. Blood samples were also passed onto Vero cells and the cultures were observed daily for cytopathic effect.

\section{Statistical Analysis}

The proportion of animals showing detectible antibody titres was compared between the vaccine groups using the Student t-test. A significance level of $\mathrm{p}=0.05$ was used.

\section{Results}

\section{Kinetics of CL13 and CL13T virus multiplication}

The RVFV CL13T reached a titer of $10^{8.7} \mathrm{TCID}_{50} / \mathrm{ml}$ two days post inoculation (dpi) of Vero cells. The highest titre of CL13 virus $\left(10^{7.0}\right.$ $\mathrm{TCID}_{50} / \mathrm{ml}$ ) was obtained at $3 \mathrm{dpi}$ of the Vero cells. The titres of both viruses then decreased progressively; at $4 \mathrm{dpi}$ the CL13T titre was $10^{7.6}$ $\mathrm{TCID}_{50} / \mathrm{ml}$ and the CL13 was $10^{5.7} \mathrm{TCID}_{50} / \mathrm{ml}$ (Figure 1 ).

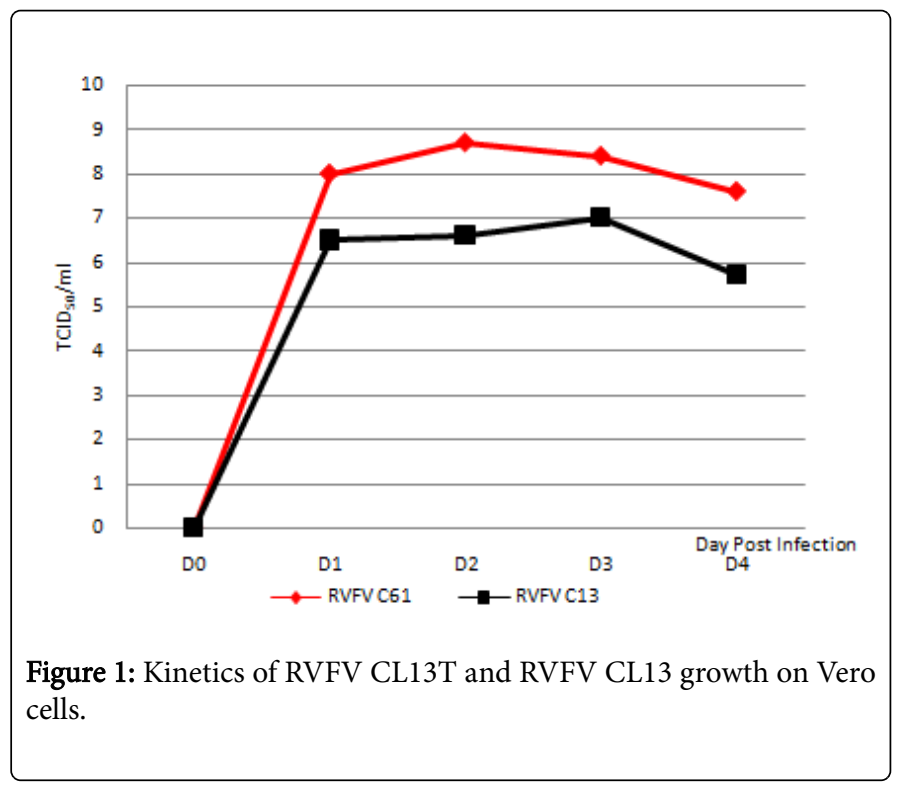


Citation: Daouam S, Ghzal F, Arkam AE, Naouli Y, Jazouli, et al. (2015) Evaluation of the Safety and Efficacy of a Live Attenuated Thermostable Rift Valley Fever Vaccine in Sheep, Goats and Cattle. J Vaccines Vaccin 6: 295. doi: 10.4172/2157-7560.1000295

Page 3 of 6

\section{Thermostability of CL13 and CL13T candidate vaccine viruses}

No loss in infectivity was observed after incubating the liquid form of the CL13T candidate vaccine virus for 4 days at $37^{\circ} \mathrm{C}$, while at the same temperature and incubation time the CL13 vaccine virus lost all its infectivity (Figure 2A).
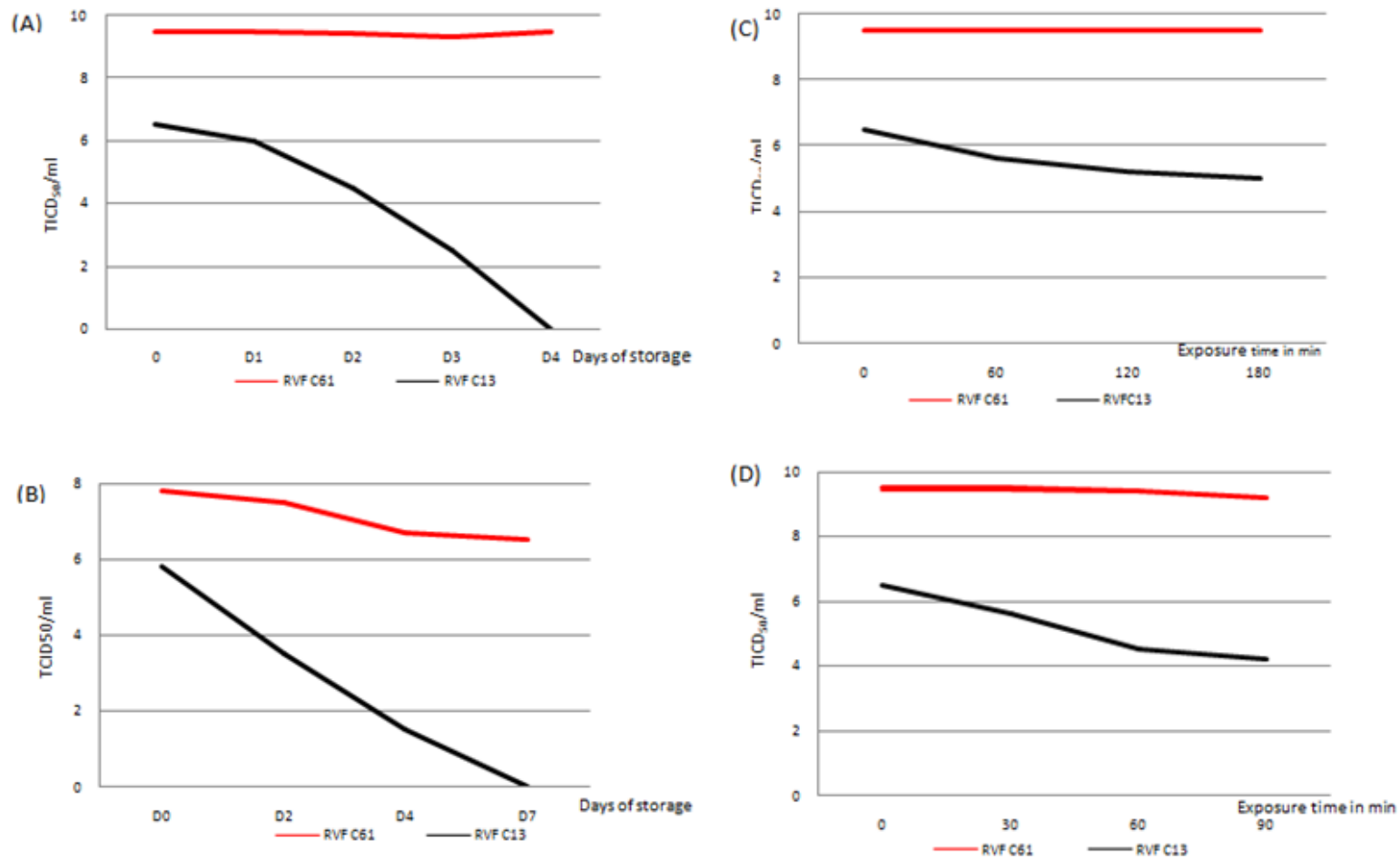

Figure 2: Temperature stability of RVFV CL13 and RVFV CL13T in liquid form at $37^{\circ} \mathrm{C}(\mathrm{A})$ and in a lyophilized form at $37^{\circ} \mathrm{C}(\mathrm{B})$, at $45^{\circ} \mathrm{C}(\mathrm{C})$ and $56^{\circ} \mathrm{C}(\mathrm{D})$.

The freeze-dried CL13T vaccine, stored at $4^{\circ} \mathrm{C}$ for a 20 month period, showed a drop of $1 \log \mathrm{TCID}_{50}$ in infectious titre (7.8 to $6.8 /$ $\mathrm{ml})$, while the freeze-dried CL13 vaccine, stored at $4^{\circ} \mathrm{C}$ for a 12 month period, decreased in titre from 5.8 to less than 4.0 (data not shown). When stored for 7 days at $37^{\circ} \mathrm{C}$, the titre of the freeze-dried CL13T vaccine decreased from 7.8 to 6.2 , whereas during the same time period the CL13 vaccine lost all its infectivity (Figure 2B). Additionally, the CL13T vaccine virus remained stable for more than 3 hours at $45^{\circ} \mathrm{C}$, during which time the CL13 lost over a log of infectivity (Figure 2D). The CL13T vaccine virus remained stable for $90 \mathrm{~min}$ at $56^{\circ} \mathrm{C}$, whereas during the same time period the CL13 vaccine virus lost nearly 3 logs of infectivity (Figure 2C).

Not enough sensibility to differentiate between CL13 and CL13T, the obtained value for the melting point is $167.5^{\circ} \mathrm{C}$ for RVF CL13T and $166.8^{\circ} \mathrm{C}$ for RVFCL13.

\section{Safety testing of CL13T candidate vaccine}

Normal body temperatures were recorded in all the sheep, goats and cattle post-vaccination with different doses $\left(10^{4}\right.$ to $\left.10^{8} \mathrm{TCID}_{50}\right)$ of the CL13T candidate vaccine virus (data not shown). No abnormal behavior, clinical signs or local reactions at the injection sites were observed in any of the vaccinated animals.
EDTA blood, collected from day 0 to day 15 post-vaccination, was tested for the presence of RVFV by virus isolation on Vero cells and for RVFV RNA by real-time RT-PCR. No live virus or viral RNA was detected in any of the post-vaccination samples, indicating that the vaccine virus was not circulating in the vaccinated animals.

\section{Serological responses in animals vaccinated with the CL13T candidate vaccine virus}

All cattle that were vaccinated with different doses of the CL13T candidate vaccine seroconverted as shown in Figure 3. Only two of the six cattle vaccinated with $10^{4} \mathrm{TCID}_{50}$ of the CL13T candidate vaccine tested positive by $\mathrm{VN}$, with both of the positive cattle having a titre of 1.5 at 42 and 56 days post vaccination (dpv) and one of the cattle having a titre of 1.02 at $86 \mathrm{dpv}$. Five out of the six cattle vaccinated with $10^{5} \mathrm{TCID}_{50}$ of the CL13T candidate vaccine tested positive with VN titres between 1.02 to 1.26 by $28 \mathrm{dpv}$.

A good neutralizing antibody response was recorded in the majority of vaccinated animals from $7 \mathrm{dpv}$ following the administration of a single dose of $10^{6}, 10^{7}$ and $10^{8}$ TCID $_{50}$ of the CL13T candidate vaccine (Figure 3). Neutralizing antibody were detected in the vaccinated cattle up to $116 \mathrm{dpv}$ in all groups, except for the group of cattle that were administrated a dose of $10^{4} \mathrm{TCID}_{50}$. 


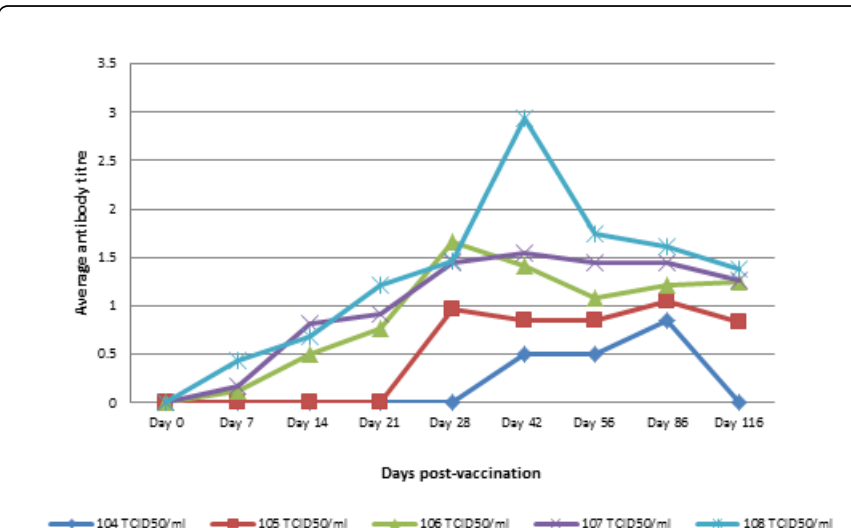

Figure 3: Average neutralizing antibody titres obtained in cattle after vaccination with RVFV CL13T at different doses $\left(10^{4}, 10^{5}, 10^{6}\right.$, $10^{7}$ and $\left.10^{8} \mathrm{TCID}_{50}\right)$.
No significant difference in the proportion of animals with detectible antibodies was found between the groups that were vaccinated with $10^{5} \mathrm{TCID}_{50}$ and $10^{6} \mathrm{TCID}_{50}(\mathrm{p}=0.147)$ and the groups vaccinated with $10^{5} \mathrm{TCID}_{50}$ and $10^{7} \mathrm{TCID}_{50}(\mathrm{p}=0.065)$. Statistically significant differences $(\mathrm{p}<0.05)$ were however observed when comparing the proportion of animals with detectible antibodies between the group vaccinated with $10^{5} \mathrm{TCID}_{50}$ and the groups vaccinated with $10^{4} \mathrm{TCID}_{50}$ and $10^{8} \mathrm{TCID}_{50}$.

High titres of antibodies, measured by both ELISA and VN, were recorded in all the vaccinated sheep and goats from $7 \mathrm{dpv}$ (Figure 4). The kinetics of the antibody responses were similar in sheep and goats and antibodies persisted in both species for up to a year postvaccination (Figure 4). All the unvaccinated control animals remained negative throughout the study, indicating that the vaccine virus was not being spread between the vaccinated and the unvaccinated animals. No statistically significant differences in serum neutralizing antibody titres were observed between sheep and goat groups $(\mathrm{p}=$ $0.320)$.
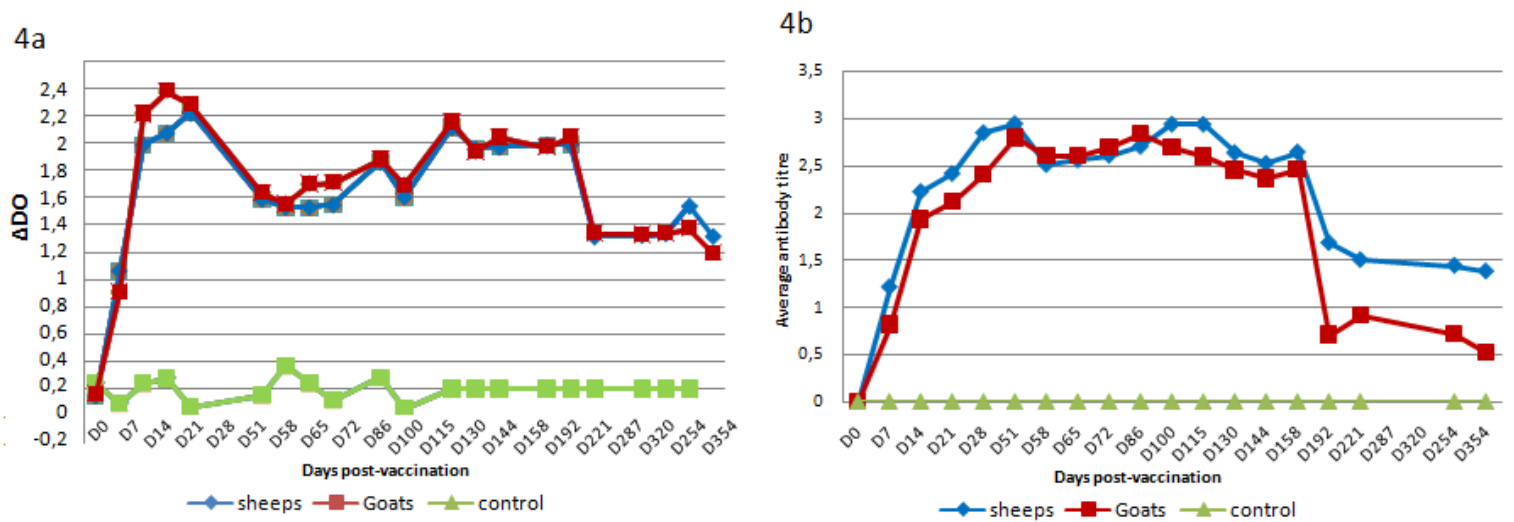

Figure 4: Average ELISA, a) and neutralizing; b) antibody titres obtained in sheep and goats after vaccination with $10^{3}$ TCID 50 of the RVF CL13T candidate vaccine.

\section{Discussion}

Live attenuated vaccines against RVF have been shown to be more efficient for disease control compared to inactivated vaccines that require an initial course of two vaccinations, followed by an annual booster vaccination $[15,16]$. The live-attenuated vaccines for RVF that are currently available either have safety problems, as with the Smithburn strain [23] or stability issues, as with the thermolabile CL13 vaccine [20].

In this study, we report the isolation and characterization of a new thermostable RVF CL13T candidate vaccine, derived from the CL13 vaccine strain through a heating and cloning method. This 'heating and cloning' technique has been used in the past to develop thermostable vaccines that have been successfully used in the field; examples include the thermostable Rinderpest and Sheep pox vaccines [24,25].

The kinetics of virus replication on Vero cells, as well as the thermostability at $4^{\circ} \mathrm{C}, 37^{\circ} \mathrm{C}, 45^{\circ} \mathrm{C}$ and $56^{\circ} \mathrm{C}$ has been compared between the CL13T candidate vaccine strain and the original CL13 vaccine virus. When the CL13 vaccine virus was propagated in cell culture, the maximum viral titre occurred after 2 or $3 \mathrm{dpi}$, depending on the MOI [26]. A similar result was obtained in this current study, with the titre of the CL13 virus peaking at $3 \mathrm{dpi}$ and the titre of the CL13T virus peaking at $2 \mathrm{dpi}$. Interestingly, the CL13T reached a titre of $10^{8.5} \mathrm{TCID}_{50} / \mathrm{ml}$, whereas the CL13 reached a maximum titre of $10^{7.5} \mathrm{TCID}_{50} / \mathrm{ml}$. This indicates that the cloning process also increased the fecundity of the selected virus (CL13T), producing a virus that replicated more rapidly, reaching higher peak viral titres on Vero cells. These properties would have obvious advantages for vaccine production.

As regards thermostability, the CL13T vaccine candidate strain was more stable for longer time periods than the CL13 strain at normal storage conditions $\left(4^{\circ} \mathrm{C}\right)$. The CL13T strain was also more resistant to heating than the CL13 strain. A previous study also confirmed the lack of thermostability of the CL13 vaccine strain [20]. 
This study indicates that the CL13T vaccine strain is safe for use in cattle and small ruminants. No side effects, clinical signs or rises in body temperature were observed in the vaccinated animals, even when very high doses of the vaccine were administered. Additionally, RVFV or viral RNA was not detected in the blood of the vaccinated animals by virus isolation or real-time RT-PCR, showing that the vaccine virus was not circulating post-vaccination in the blood of vaccinated animals. The CL13 vaccine has previously been demonstrated to be safe to use in pregnant animals, so it is highly likely that the CL13T vaccine virus, which is derived from the CL13 vaccine virus and contains the same deleted NSs segment as CL13, will also be safe for use in pregnant animals [18].

The optimum protective dose of the CL13T candidate vaccine has been established in cattle, sheep and goats. In cattle the effect of the vaccine dose is clear; earlier and higher neutralizing antibody titres were observed in cattle as the dose of virus in the vaccine was increased. A dose of $10^{5} \mathrm{TCID}_{50}$ resulted in a good serological response in the vaccinated cattle, while in small ruminants (sheep and goats) a lower dose of $10^{3} \mathrm{TCID}_{50}$ conferred a good and long-lasting serological response. These findings are in accordance with reported results for the Smithburn and CL13 strains $[18,19]$, however the neutralizing titres observed post-vaccinated with the CL13T vaccine were more pronounced and longer lasting than that seen with the Smithburn and CL13 strains, This serological response may be enhanced by the use the specific adjuvant such [27].

In conclusion, this study reports the development and characterization of a thermostable live attenuated RVF vaccine. The new CL13T candidate vaccine, which was derived from the deleted CL13 vaccine, is stable at $4^{\circ} \mathrm{C}$ for 20 months and shows improved levels of thermostability over the existing CL13 vaccine. The CL13T vaccine was safe, with no clinical signs or side effects observed in vaccinated animals, and there was no evidence for the circulation of the virus in the blood of animals post-vaccination. On testing for efficacy in cattle, sheep and goats, through the detection of neutralizing antibodies postvaccination, good levels of neutralizing antibodies were detected for a minimum of one year in sheep and goats, and neutralizing antibodies were detected for a least 4 months in cattle. This new thermostable vaccine could represent an efficient tool for the control of rift valley fever in endemic countries and also has the potential to be used, along with an appropriate diagnostic test to differentiating infected from vaccinated animals (DIVA).

\section{References}

1. Giorgi C, Accardi L, Nicoletti L, Gro MC, Takehara K, et al. (1991) Sequences and coding strategies of the S RNAs of Toscana and Rift Valley fever viruses compared to those of Punta Toro, Sicilian Sandfly fever, and Uukuniemi viruses. Virology 180: 738-53.

2. Flick R, Bouloy M (2005) Rift Valley fever virus. Curr Mol Med 5 827-834.

3. Pepin M, Bouloy M, Bird BH, Kemp A, Paweska J (2010) Rift Valley fever virus (Bunayviridae: Phlebovirus): an update on pathogenesis, molecular epidemiology, vectors, diagnostics and prevention. Vet Res 41: 61.

4. Easterday BC, Mcgavran MH, Rooney JR, Murphy LC (1962) The pathogenesis of Rift Valley fever in lambs. Am J Vet Res 23: 470-479.

5. Coetzer JA (1977) The pathology of Rift Valley fever. I. Lesions occurring in natural cases in new-born lambs. Onderstepoort J Vet Res 44: 205-211.

6. Coetzer JA, Barnard BJ (1977) Hydrops amnii in sheep associated with hydranencephaly and arthrogryposis with wesselsbron disease and rift valley fever viruses as aetiological agents. Onderstepoort J Vet Res 44 119-126.
7. Shoemaker T, Boulianne C, Vincent MJ, Pezzanite L, Al-Qahtani MM, et al. (2002) Genetic analysis of viruses associated with emergence of Rift Valley fever in Saudi Arabia and Yemen, 2000-01. Emerg Infect Dis 8: 1415-1420.

8. Sissoko D, Giry C, Gabrié P, Tarantola A, Pettinelli F, et al. (2009) Émergence chez l'homme de la fièvre de la vallée du Rift à Mayotte, 2007-2008. BEH 4: 33-36.

9. Sissoko D, Giry C, Gabrie P, Tarantola A, Pettinelli F, et al. (2009) Rift Valley fever, Mayotte, 2007-2008. Emerg Infect Dis 15: 568-570.

10. El-Harrak M, Martín-Folgar R, Llorente F, Fernández-Pacheco P, Brun A, et al. (2011) Rift Valley and West Nile virus antibodies in camels, North Africa. Emerg Infect Dis 17: 2372-2374

11. Fafetine J, Neves L, Thompson PN, Paweska JT, Rutten VP, et al. (2013) Serological evidence of Rift Valley fever virus circulation in sheep and goats in Zambézia Province, Mozambique. PLoS Negl Trop Dis 7: e2065.

12. Botros B, Omar A, Elian K, Mohamed G, Soliman A, et al. (2006) Adverse response of non-indigenous cattle of European breeds to live attenuated Smithburn Rift Valley fever vaccine. J Med Virol 78: 787-791.

13. [No authors listed] (1983) The use of veterinary vaccines for prevention and control of Rift Valley fever: memorandum from a WHO/FAO meeting. Bull World Health Organ 61: 261-268.

14. Davies FG(1981) Rift Valley fever in Kenya. Proceedings of the 49th General Session of the Office International des Epizooties, Paris.

15. Barnard BJ, Botha MJ (1977) An inactivated rift valley fever vaccine. J S Afr Vet Assoc 48: 45-48.

16. Barnard BJ (1979) Rift Valley fever vaccine--antibody and immune response in cattle to a live and an inactivated vaccine. J S Afr Vet Assoc 50: 155-157.

17. Muller R, Saluzzo JF, Lopez N, Dreier T, Turell M, et al. (1995) Characterization of clone 13 , a naturally attenuated avirulent isolate of Rift Valley fever virus, which is altered in the small segment. Am J Trop Med Hyg 53: 405-411.

18. Dungu B, Louw I, Lubisi A, Hunter P, von Teichman BF, et al. (2010) Evaluation of the efficacy and safety of the Rift Valley Fever Clone 13 vaccine in sheep. Vaccine 28: 4581-4587.

19. von Teichman B, Engelbrecht A, Zulu G, Dungu B, Pardini A, et al. (2011) Safety and efficacy of Rift Valley fever Smithburn and Clone 13 vaccines in calves. Vaccine 29: 5771-5777.

20. Daouam S, Fakri FZ, Ennaji MM, El arkam A, Tadlaoui KO, et al. (2014) Heat stability of the Rift Valley Fever Virus Clone 13 live vaccines. Trials in Vaccinology 3: 61-64.

21. International Committee of the OIE (2008) In: OIE Biological Standards Commission (eds.) Manual of diagnostic tests and vaccines for terrestrial animals (6thedn.) World Organisation for Animal Health, France.

22. Anyangu AS, Gould LH, Sharif SK, Nguku PM, Omolo JO, et al. (2010) Risk factors for severe Rift Valley fever infection in Kenya, 2007. Am J Trop Med Hyg 83: 14-21.

23. Hunter P, Erasmus BJ, Vorster JH (2002) Teratogenicity of a mutagenised Rift Valley fever virus (MVP 12) in sheep. Onderstepoort J Vet Res 69: 95-98.

24. Provost A, Buedon C (1972) Un vaccin mixte anti bovipestique anti péripneumonique lyophilisé utilisable sur le terrain sans réfrigération. Rev Elev Med.Vet pays trop 27: 251-263.

25. El Harrak M (1987) Sélection d'une souche thermostable du virus de la clavelée et son utilisation dans la préparation d'un vaccin attenue. Institut Agronomique Veterinaire Hassan II, Morocco.

26. Billecocq A, Vialat P, Bouloy M (1996) Persistent infection of mammalian cells by Rift Valley fever virus. J Gen Virol 77: 3053-3062.

27. Rajagopal A, Charles BC, Alexey YK, Joshua DS, Frederick JK, et al. (2015) Enhancing the Magnitude of Antibody Responses through Biomaterial Stereochemistry. ACS Biomater Sci Eng 1: 601-609. 